\author{
G.J. Sultangazina $^{1 *}$, A.N. Kuprijanov², O.A. Kuprijanov², M.Y. Steshenko ${ }^{1}$ \\ ${ }^{I}$ A. Baitursynov Kostanay State University, Kazakhstan; \\ ${ }^{2}$ Kuzbass Botanical garden, Federal Research Center of Coal and Coal Chemistry of SB RAS, Kemerovo, Russia; \\ (*E-mail:gul_sultan@mail.ru)
}

\title{
The structure of Adonis wolgensis Stev. coenopopulation in the conditions of Northern Kazakhstan
}

\begin{abstract}
The article presents the study results made on the Adonis wolgensis coenopopulation in Northern Kazakhstan (2018-2019). The materials have been gathered in the course of field research taking into account the literary data. The age structure of the coenopopulations is provided on the basis of detailed route studies. There have been studied eight coenopopulations located in Akmola, Pavlodar, and Kostanay regions. A. wolgensis is a short-stem herbaceous polycarpic of Northern Kazakhstan. A. wolgensis coenopopulations are found in three main habitats: steppe, meadow-steppe, and forest communities. The study of $A$. wolgensis coenopopulations in the latitudinal direction from Ekibastuz in the east to the Kostanay region in the west has revealed a high recovery index in steppe ecotopes. In other coenopopulations it is less than one. It is especially low in forest habitats. Most coenopopulations have a normal character according to the spectrum of age conditions, and they are maturing. This fact proves no negative impact of environmental and anthropogenic factors on the structure of coenopopulations and ensures their recovery and preservation.
\end{abstract}

Keywords: Adonis wolgensis Stev., coenopopulation, Northern Kazakhstan, age structure, rare plants.

\section{Introduction}

Adonis wolgensis Stev. is in the Red Book of Kazakhstan (category III). Dying species) [1]. The species is protected in Ukraine, the Republic of Moldova, Bulgaria, Romania [2-5], as well as in 11 regions of the Russian Federation.

\section{Material and research methods}

Age structure is one of the essential signs of cenopopulation, as it provides the ability of the population system to maintain itself and to determine its stability [7]. The study of Adonis wolgensis Stev.'s age structure was held in Northern Kazakhstan in 2018-2019. There have been studied 8 coenopopulations of $A$. wolgensis located in Akmola, Pavlodar, and Kostanay regions. The area of maximal distribution of $A$. wolgensis was determined for each CP using GPS; 25 reference sites $\left(1 \mathrm{~m}^{2}\right)$ were made inside the CPs on which the number of all $A$. wolgensis specimens was counted and their age stages were determined.

The age stages were determined according to the guidelines of T.A. Rabotnov [8], A.A. Uranov [9-10], L.B. Zaugolnova and O.V. Smirnova [7], Plant coenopopulations... [11].

The type of coenopopulation was determined according to T.A. Rabotnov [8] and to the «delta-omega» classification of L.A. Zhivotovsky [12].

The age index of a coenopopulation $(\Delta)$ is calculated according to the formula

$$
\Delta=\Sigma K_{i} m_{i} / \Sigma K_{i}
$$

i.e. $\Sigma K_{i}$ is a sum of the plants of all age stages; $m_{i}$ is the age of individual plants [13].

The efficiency index was defined by the formula

$$
\omega=\Sigma p_{i} e_{i}
$$

i.e. $p_{i}=n_{i} / n$ is the share of plants of an $i$-state in this population, $n_{i}$ is the absolute number of $i$-state plants, $n=\Sigma n_{i}$ is the total number of plants, $e_{i}$ is energy efficiency [13].

The recovery index $(I)$ was calculated by the formula

$$
I=\Sigma j \rightarrow v / \Sigma g 1 \rightarrow g 3,
$$

i.e. $\Sigma j \rightarrow v$ is the sum of plants of all age stages of the pre-generative period; $\Sigma g 1 \rightarrow g 3$ is the sum of plants of all age stages of the generative period [13]. 


\section{Results and discussion}

A. wolgensis is a short-stem herbaceous polycarpic plant of Northern Kazakhstan represented by three morphotypes: steppe, meadow-steppe, and forest ones. They all have significant morphological differences in the height of shoots and the form of leaf blades.

CP-1. Pavlodar region, near Ekibastus, $51.66494^{\circ} \mathrm{N}, 75.28173^{\circ} \mathrm{E}, h=412$ m.a.s.l. Interslope lowland, northern slope, adonis-fescue community. The population area is $200 \mathrm{~m}^{2}$, total projective cover (TPC) is $60 \%$, the TPC of $A$. wolgensis is $40 \%$, the community has 24 species. The vegetation is formed by Adonis wolgensis, Alyssum desertorum, Androsace maxima, Artemisia austriaca, Festuca valesiaca, Potentilla humifusa, Ranunculus polyrhizos, Seseli ledebourii, Valeriana tuberosa.

CP-2. Pavlodar region, near Ekibastus, «Three birches» tract, $51.57517^{\circ} \mathrm{N}, 75.13187^{\circ} \mathrm{E}, h=403$ m.a.s. 1 . Eastern slope of the hill, feather-grass and fescue steppes on alkaline soils. The population area is $300 \mathrm{~m}^{2}$, TPC is $60 \%$, the TPC of $A$. wolgensis is $0.5 \%$, the community has 29 species. The vegetation is formed by Artemisia nitrosa, Astragalus testiculatus, Draba nemorosa, Festuca valesiaca, Limonium gmelinii, Ranunculus polyrhizos, Spiraea hypericifolia, Tulipa patens, Valeriana tuberosa.

CP-3. Pavlodar region, near Bayanaul, 50.2209 $\mathrm{N}, 75.8009^{\circ} \mathrm{E}, 406$ m.a.s.1. The foot of the slope, the shrubs of a fescue-feather grass steppe. The population area is $500 \mathrm{~m}^{2}$, TPC is $90 \%$, the TPC of A. wolgensis is $0,5 \%$, the community has 29 species. The vegetation is formed by Allium nutans, Caragana frutex, Carex pediformis, Gagea granulosa, Poa angustifolia, Rosa spinosissima, Seseli libanotis, Stipa capillata, S. pennata, Thymus marschallianus.

CP-4. Akmola region, near Ereimentau, the Ereimentau mountains, $51.65717^{\circ} \mathrm{N}, 73.19056^{\circ} \mathrm{E}$, $h=313$ m.a.s.l. The foot of the slope is the alkaline meadow. The population area is $400 \mathrm{~m}^{2}$, TPC is $100 \%$, the TPC of A. wolgensis is $3.0 \%$, the community has 25 species. The vegetation is formed by Agropyron cristatum, Artemisia dracunculus, Carduus nutans, Centaurea scabiosa, Glycyrrhiza uralensis, Potentilla bifurca, Ranunculus polyanthemos, Rumex acetosa, Tamarix ramosissima.

CP-5. Akmola region, the Burabay region, near Kartakol, $52.93287^{\circ} \mathrm{N}, 70.49210^{\circ} \mathrm{E}, h=431$ m.a.s.1. Pine and birch forest. The population area is $300 \mathrm{~m}^{2}$, TPC is $60 \%$, the TPC of A. wolgensis is $0.5 \%$, the community has 20 species. The vegetation is formed by Achillea asiatica, Betula pendula, Calamagrostis epigeios, Equisetum hyemale, Filipendula ulmaria, Jacobaea erucifolia, Pinus sylvestris, Populus tremula, Rosa majalis, Solidago virgaurea,

CP-6. Kostanay region, near Scherbakovo, $53.20453^{\circ} \mathrm{N}, 64.21550^{\circ} \mathrm{E}$. The sparse pine forest is growing on sands. Population area is $1000 \mathrm{~m}^{2}$, OPP is $30 \%$, the OPP of A. wolgensis is $0.5 \%$. The community has 22 species. The vegetation is formed by Agropyron pectinatum, Carex supina, Genista tinctoria, Phragmites australis, Potentilla arenaria, Scorzonera ensifolia, Stipa capillata, Thymus serpyllum, Tulipa biebersteiniana, Veronica spicata.

CP-7. Kostanay region, near Ozerny, the Novonezhensky forestry, sq. $21,52.43971^{\circ} \mathrm{N}, 64.09279^{\circ} \mathrm{E}$, $h=213$ m.a.s.l. The secondary psammophyte steppe is at the site of an old fire. Population area is $300 \mathrm{~m}^{2}$, OPP is $100 \%$, the OPP of A. wolgensis is $5.0 \%$. The community has 38 species: Artemisia campestris, Echinops sphaerocephalus, Gypsophila paniculata, Medicago falcata, Oenothera biennis, Otites wolgensis, Potentilla arenaria, Pulsatila uralensis, Sedum telephium, Xanthoselinum alsaticum,

$\mathrm{CP}-8$. Kostanay region, near Zarechny, «Stone Lake», 52.28013 N, $63.76616^{\circ} \mathrm{E}, h=134$ m.a.s.l. The northern slope towards the lake, shrub thickets. Population area is $400 \mathrm{~m}^{2}$, OPP is $100 \%$, the OPP of A. wolgensis is $1.0 \%$. The community has 23 species: Amygdalus nana, Calamagrostis epigeios, Filipendula vulgaris, Potentilla bifurca, Rosa acicularis, R. spinosissima, Spiraea hypericifolia, Stipa capillata, S. pennata.

A. wolgensis coenopopulations are confined to three main habitats: steppe communities (CP-1, CP-2, CP-7), meadow-steppe communities (CP-3, CP-4, CP-8), forest communities (CP-5, CP-6). Many authors who studied the structure of $A$. wolgensis coenopopulations consider it to be a steppe species. Forest habitats are not peculiar to it [14-16]. Therefore, forest habitats should be considered secondary for A. wolgensis. In this regard, the presence of $A$. wolgensis in a pine-birch forest can be explained by some dynamic processes of «forest fighting with steppe» in the process of climatic fluctuations in the Kokshetau highlands.

By density (pcs. $/ 100 \mathrm{~m}^{2}$ ) all populations are divided into three groups: high $>800 \mathrm{pcs} . / 100 \mathrm{~m}^{2}$ (CP-1, CP-7), medium - 150-800 pcs./100 m² (CP-3, CP-4, CP-6, CP-8), low < 150 (CP-2, CP-5). Steppe CPs (except CP-2) have high density, meadow-steppe ones are medium, forest $\mathrm{CPs}$ are low or medium (Table 1). 
Characteristics of $\boldsymbol{A}$. wolgensis coenopopulation

\begin{tabular}{|c|c|c|c|c|c|c|c|c|}
\hline No. & TPC, \% & $\begin{array}{c}\text { TPC } \\
\text { A. wolgensis, } \%\end{array}$ & $\begin{array}{c}\text { Area of CP, } \\
\mathrm{m}^{2}\end{array}$ & $\begin{array}{c}\text { Density of } \\
\text { plants, } \\
\text { pcs./100 } \mathrm{m}^{2}\end{array}$ & $\begin{array}{c}\text { Number of } \\
\text { plants in CP }\end{array}$ & $\Delta$ & $\omega$ & $\mathrm{I}$ \\
\hline CP-1 & 60 & 40.0 & 200 & 1480 & 2960 & 0.47 & 0.62 & 0.65 \\
\hline CP-2 & 60 & 0.5 & 300 & 51 & 153 & 0.20 & 0.59 & 1.43 \\
\hline CP-3 & 90 & 0.5 & 500 & 169 & 845 & 0.30 & 0.77 & 0.32 \\
\hline CP-4 & 100 & 3.0 & 400 & 490 & 1960 & 0.29 & 0.75 & 0.32 \\
\hline CP-5 & 60 & 0.5 & 300 & 85 & 255 & 0.33 & 0.86 & 0.06 \\
\hline CP-6 & 30 & 0.5 & 1000 & 315 & 3150 & 0.32 & 0.81 & 0.31 \\
\hline CP-7 & 100 & 5.0 & 300 & 870 & 2610 & 0.22 & 0.64 & 1.07 \\
\hline CP-8 & 100 & 1.0 & 400 & 155 & 620 & 0.27 & 0.84 & 0.63 \\
\hline
\end{tabular}

According to the age structure, mature (CP-1) and maturing (CPU-2) species grow only in steppe coenopopulations, all the rest are young (Table 2). By the «delta-omega» ratio, most populations are maturing, but $\mathrm{CP}-1$ is the one which is transitive and $\mathrm{CP}-2$ is young.

The recovery index (Table 1 ) in steppe ecotopes is very high $0.65-1.43$. In other CPs it is less than one. It is especially low in CP-5 (forest habitats) where it is 0.06 (Table 1).

Characteristics of $\boldsymbol{A}$. wolgensis according to the age ratio and «delta-omega» (by Zhivotovsky, 2001)

\begin{tabular}{|c|c|c|}
\hline No. & Age ratio & «delta - omega» \\
\hline CP-1 & Mature & Transitive \\
\hline CP-2 & Maturing & Young \\
\hline CP-3 & Young & Maturing \\
\hline CP-4 & Young & Maturing \\
\hline CP-5 & Young & Maturing \\
\hline CP-6 & Young & Maturing \\
\hline CP-7 & Young & Maturing \\
\hline CP-8 & Young & Maturing \\
\hline
\end{tabular}

All the coenopopulations of $A$. wolgensis are normal with slight deviations. The exception is CP-2 located on the eastern slope of the hill in the lowland. There is a long-lasting snow cover that provides favorable conditions for resumption. As a result, a large number of young vegetative plants and CPs has antropogenous invasive character. Inconsistency of the CP is bound to an extremely small number of senile plants and seedings.

\section{Conclusion}

Thus, the study of $A$. wolgensis CPs in a latitude direction from Ekibastus in the east to the Kostanay region in the west has found that the majority of CPs has normal character and belongs to maturing CPs according to the spectrum of age stages. This fact proves no negative impact of environmental and anthropogenic factors on the structure of coenopopulations and ensures their recovery and preservation. The gathered data are consistent with the study results of $A$. wolgensis coenopopulations in the Saratov's region $[17,18]$.

The research was carried out within the framework of grant financing project of the Ministry of Education and Science, the Republic of Kazakhstan for 2018-2020. «Molecular genetic analysis of gene pools of rare plant species populations in Northern Kazakhstan» № AP05132458, number of the state registration is $0118 R K 00404$.

\section{References}

1 Красная книга Казахстана. - Т. 2, Ч. 2. Растения / 2-е изд., испр. и доп. — Астана: «Art-Print XXI» Ltd, 2014. $452 \mathrm{c}$. 
2 Червона книга України. Рослинний світ. - Киев: Глобалконсалтинг, 2009. — 900 с.

3 Червена книга на НБ България. Изчезнали, застрашены от изчезване и редки растения и животны. - Т. 1. Растения. - София, 1984. - $418 \mathrm{c}$.

4 Кондратюк Е.Н. Редкие, эндемичные и реликтовые растения юго-востока Украины в природе и в культуре / Е.Н. Кондратюк, В.М. Остапенко. — Киев: Наук. думка, 1990. — 152 с.

5 Dihoru G. Plante rare, pericitate sie endemic in flora Romaniei. Lister Rosie / G. Dihoru // Lucr Grad. Bot. Bucarest. 1984. - P. 173-197.

6 Adonis wolgensis. — URL: www plantarium.ru [дата обращения 05.01.2020].

7 Заугольнова Л.Б. Возрастная структура ценопопуляций многолетних растений и ее динамика / Л.Б. Заугольникова, О.В. Смирнова // Журн. общ. биол. - 1978. - Т. 39. - С. 849-858.

8 Работнов Т. А. Жизненный цикл многолетних травянистых растений в лесных ценозах / Т.А. Работнов // Тр. БИН АН СССР. - Сер. 3. - 1950. - Вып. 6. - С. 7-204.

9 Уранов А.А. Возрастной спектр фитоценопопуляций как функция времени и энергетических процессов / А.А. Работнов // Биологические науки. — 1975. — № 2. - С. 7-34.

10 Уранов А.А. Онтогенез и возрастной состав популяций // Онтогенез и возрастной состав популяций цветковых растений / А.А. Уранов. — М.: Наука, 1967. — С. 3-8.

11 Смирнова О.В. Критерии выделения возрастных состояний и особенности хода онтогенеза у растений разных биоморф / О.В. Смирнова, Л.Б. Заугольнова, Н.А. Торопова, Л.Д. Фаликов // Ценопопуляции растений (основные понятия и структура). - М.: Наука, 1976. - С. 14-44.

12 Животовский Л.А. Онтогенетические спектры, эффективная плотность и классификация популяций растений / Л.А. Животовский // Экология. — 2001. - № 1. - С. 3-7.

13 Жукова Л.А. Динамика популяций луговых растений в естественных фитоценозах // Динамика популяций травянистых растений / Л.А. Жукова. - Киев: Наук. думка, 1987. — С. 9-19.

14 Romenska O.V. The impact of anthropogenic factors on the age structure of Adonis wolgensis (Ranunculaceae) populations / O.V. Romenska, M.V. Netsvetov // Укр. бот. журн. — 2016. — № 73(5). — C. 440-452.

15 Ильина В.Н. Некоторые итоги изучения ценопопуляций адониса весеннего и волжского (Adonis vernalis L., A. wolgensis Stev.) в бассейне Средней Волги / В.Н. Ильина, С.В. Саксонов // Бюл. Гл. бот. сада. — 2010. — Вып. 196. C. 107-116.

16 Мельник В.І. Еколого-ценотичні умови місцезростань Adonis wolgensis Steven (Ranunculaceae Juss.) в Україні / В.І. Мельник, Д.Ю. Шевченко, В.В. Гриценко // Інтродукція рослин. — 2015. — No. 4. — C. 37-43.

17 Давиденко О.Н. Состояние популяций адониса волжского (A. wolgensis Stev.) в Саратовской области / О.Н. Давиденко, С.А. Невский, Т.Н. Давиденко // Изв. Саратов. ун-та. Нов. сер. Химия. Биология. Экология. — 2016. — Т. 16, Вып. 2. — C. $221-225$.

18 Ермолаева Н.Н. Состояние ценопопуляций Adonis wolgensis в Саратовской области / Н.Н. Ермолаева, Н.В. Шилова, Н.А. Петрова, А.О. Попова // Бюл. Бот. сада Саратов. гос. ун-та. - 2015. - Вып. 13. - С. 40-49.

\title{
Г.Ж. Сұлтанғазина, А.Н. Куприянов, О.А. Куприянов, М.Ю. Стешенко Солтүстік Қазақстан жағдайындағы Adonis wolgensis Stev ценопопуляциясының құрылымы
}

\begin{abstract}
Мақалада Солтүстік Қазақстандағы Adonis wolgensis ценопопуляцияларын зерттеу нәтижелері келтірілген (2018-2019 жж.). Материалдар далалық зерттеулер нәтижесінде алынған, әдеби мәліметтер ескерілген. Егжей-тегжейлі бағыттық зерттеулер негізінде ценопопуляциялардың жас құрылымы келтірілген. Ақмола, Павлодар, Қостанай облыстарында орналасқан сегіз ценопопуляция зерттелді. A. wolgensis қысқа-өзекті шөпті поликарпик, ал Солтүстік Қазақстанда A. wolgensis ценопопуляциясы негізгі үш мекендейтін жерге: дала қоғамдастықтары, шалғынды-дала, орманды деп топтастырылған. A. wolgensis ценопопуляциясын шығыста Екібастұздан, батыста Қостанай облысына дейін ендік бағытта зерттеу барысында дала экотоптарындағы қалпына келтіру индексі өте жоғары екенін анықталды. Қалған ценопопуляция, ол бірліктен әлдеқайда аз. Әсіресе, орманды жерлерде аз кездеседі. Жас жағдайының спектрі бойынша көптеген ценопопуляциялар қалыпты сипатқа ие және піскендер қатарына жатады. Бұл ценопопуляциясының құрылымына экологиялық және антропогендік факторлардың теріс әсерінің жоқтығын растайды және популяциялардың жаңартылуы мен сақталуын қамтамасыз етеді.
\end{abstract}

Кiлm сөздер: Adonis wolgensis Stev., ценопопуляция, Солтүстік Қазақстан, жас құрылымы, сирек өсімдіктер. 


\title{
Г.Ж. Султангазина, А.Н. Куприянов, О.А. Куприянов, М.Ю. Стешенко
}

\section{Структура ценопопуляций Adonis wolgensis Stev. в условиях Северного Казахстана}

\begin{abstract}
В статье даны результаты изучения ценопопуляций Adonis wolgensis в Северном Казахстане (20182019 гг.). Материалы получены в результате полевых исследований, учтены литературные данные. На основании детально-маршрутных исследований приведена возрастная структура ценопопуляций. Изучено восемь ценопопуляций, расположенных в Акмолинской, Павлодарской, Костанайской областях. A. wolgensis - коротко-стержневой травянистый поликарпик, в Северном Казахстане ценопопуляции A. wolgensis приурочены к трем основным местообитаниям: степные сообщества, луговостепные, лесные. Изучение ценопопуляций A. wolgensis в широтном направлении от Экибастуза на востоке до Костанайской области на западе выявило, что индекс восстановления в степных экотопах очень высокий. В остальных ценопопуляциях он значительно меньше единицы. Особенно он мал в лесных местообитаниях. Большинство ценопопуляций по спектру возрастных состояний имеют нормальный характер и относятся к зреющим. Это свидетельствует об отсутствии негативного влияния экологических и антропогенных факторов на структуру ценопопуляций и обеспечивает возобновляемость и сохранность популяций.
\end{abstract}

Ключевые слова: Adonis wolgensis Stev., ценопопуляции, Северный Казахстан, возрастная структура, редкие растения.

\section{References}

1 Krasnaia kniha Kazakhstana. Rasteniia [Red Book of Kazakhstan. Plants]. (Vol. 2, Part 2, 2nd ed.). (2014). Astana: «ArtPrint XXI» Ltd [in Russian].

2 Chervona kniha Ukraïni. Roslinnii svit. [Red book of Ukraine. Flora]. (2009). Kiev [in Ukrainian].

3 Chervena kniha na NB Blhariia. Izcheznali, zastrasheny ot izchezvane i redki rasteniia i zhivotny. Vol. 1. Rasteniia [Red Book of the National Library of Bulgaria. Disappeared, endangered and rare plants and animals. Vol. 1. Plants]. (1984). Sofia [in Bulgarian].

4 Kondratyuk, E.N., \& Ostapko, V.M. (1990). Redkie, endemichnye i reliktovye rasteniia yuho-vostoka Ukrainy $v$ prirode $i v$ kulture [Rare, endnmic and relic plants of southeastern Ukraine in the nature and culture]. Kiev: Naukova dumka [in Russian].

5 Dihoru, G. (1984). Plante rare, pericitate sie endemic in flora Romaniei. Lister Rosie. Lucr Grad. Bot. Bucarest., $173-197$.

6 Adonis wolgensis. URL: www plantarium.ru [date of request 05.01.2020] [in Russian].

7 Zaugolnova, L.B., \& Smirnova, O.V. (1978). Vozrastnaia struktura tsenopopuliatsii mnoholetnikh rastenii i ee dinamika [Age structure of cenopopulations of perennial plants and its dynamics]. Zhurnal obshchei biolohii - Journal of General Biology, 39, 849-858 [in Russian].

8 Rabotnov, T.A. (1950). Zhiznennyi tsikl mnoholetnikh travianistykh rastenii v lesnykh tsenozakh [Methods for determining the age and duration of life in herbaceous plants]. Trudy BIN AN SSSR - Works of Botanical Institute AS of USSR, 3(6), 7-204 [in Russian].

9 Uranov, A.A. (1975). Vozrastnoi spektr fitotsenopopuliatsii kak funktsiia vremeni i enerheticheskikh protsessov [Age range of phytocenosis populations as a function of time and energy processes]. Biolohicheskie nauki - Biological Sciences, 2, 7-34 [in Russian].

10 Uranov, A.A. (1967). Ontohenez i vozrastnoi sostav populiatsii [Ontogenesis and age structures of communities]. Ontohenez i vozrastnoi sostav populiatsii tsvetkovykh rastenii [Ontogeny and age composition of populations]. Moscow: Nauka [in Russian].

11 Smirnova, O.V., Zaugolnva, L.B., Toropova, N.A., \& Falikov, L.D. (1976). Kriterii vydeleniia vozrastnykh sostoianii i osobennosti hoda ontoheneza u rastenii raznykh biomorf [Selective criteria of age conditions and ontogenesis features in plants of different biomorphs]. Tsenopopuliatsii rastenii (osnovnye poniatiia i struktura) - Ceopopulation of plants (basic concepts and structures). Moscow: Nauka [in Russian].

12 Zhivotovskii, L.A. (2001). Ontoheneticheskie spektry, effektivnnaia plotnost i klassifikatsiia populiatsii rastenii [Ontogenetic spectra, effective density and classification of plant populations]. Ekolohiia - Ecology, 1, 3-7 [in Russian].

13 Zhukova, L.A. (1987). Dinamika populiatsii luhovykh rastenii v estestvennykh fitotsenozakh [Dynamics of meadow plant populations in natural phytocenoses]. Dinamika populiatsii travianistykh rastenii - Dynamics of communities of herbal plants. Kiev: Naukova dumka [in Russian].

14 Romenska, O.V., \& Netsvetov, M.V. (2016). The impact of anthropogenic factors on the age structure of Adonis wolgensis (Ranunculaceae) populations [The impact of anthropogenic factors on the age structure of Adonis wolgensis (Ranunculaceae) populations]. Ukrainskii botanicheskii zhurnal — Ukrainian Botanical Journal, 73(5), 440-452.

15 Ilina, V.N., \& Saksonov, S.V. (2010). Nekotorye itohi izucheniia tsenopopuliatsii adonisa vesenneho i volzhskoho (Adonis vernalis L., A. wolgensis Stev.) v basseine Srednei Volhi [Some study results on the coenopopulations of Adonis vernalis L., A. wolgensis Stev. in the basin of the Middle Volga]. Biulleten Hlavnoho botanicheskoho sada - Bulletin of Main Botanical Garden, 196, 107-116 [in Russian].

16 Melnik, V.I., Shevchenko, D.Yu., \& Gricenko, V.V. (2015). Ekoloho-tsenotichni umovi miscezrostan Adonis wolgensis Steven (Ranunculaceae Juss.) v Ukraïni [Ecological-coenotic conditions of habitat for Adonis wolgensis Steven (Ranunculaceae Juss.) in Ukraine]. Introduktsiia roslin - Plant Introduction, 4, 37-43 [in Ukrainian]. 
17 Davidenko, O.N., Nevskii, S.A., \& Davidenko, T.N. (2016). Sostoianie populiatsii adonisa volzhskoho (A. wolgensis Stev.) v Saratovskoi oblasti [The state of A. wolgensis Stev. populations in the Saratov rehion]. Izvestiia Saratovskoho universiteta. Novaia seriia. Khimiia. Biolohiia. Ekolohiia - Bulletin of Saratov University. New series. Chemistry, Biology, Ecology, 16(2), $221-225$ [in Russian].

18 Ermolaeva, N.N., Shilova, N.V., Petrova, N.A., \& Popova, A.O. (2015). Sostoianie tsenopopuliatsii Adonis wolgensis v Saratovskoi oblasti [The state of Adonis wolgensis coenopopulations in the Saratov region]. Biulletten Botanicheskoho sada Saratovskoho hosudarstvennoho universiteta - Bulletin of Botanical Garden of Saratov State University, 13, 40-49 [in Russian]. 